\title{
Acidic and alkaline bimolecular hydrolysis of substituted formanilides. Computational analysis and modelling of substitution effects
}

\author{
Martin Michalík, Peter Škorňa, Vladimír Lukeš, Erik Klein \\ Institute of Physical Chemistry and Chemical Physics, Slovak University of Technology in Bratislava, \\ Radlinského 9, SK-812 37 Bratislava, Slovakia \\ martin.michalik@stuba.sk
}

\begin{abstract}
In this article, the study of 67 compounds representing various para-, meta- and ortho- substituted formanilides is presented. These molecules and the products of their acidic and alkaline hydrolysis were studied using DFT quantum chemical methods in order to calculate the reaction enthalpies. These enthalpies are correlated with the hydrolysis rate constants, $\mathrm{k}_{\mathrm{H}}$, published for the acid-catalysed acyl cleavage bimolecular $\left(\mathrm{A}_{\mathrm{AC}} 2\right)$ mechanism and the modified base-catalysed acyl cleavage bimolecular $\left(\mathrm{B}_{\mathrm{AC}} 2\right)$ mechanism. The found linear dependences can be used for the prediction of rate constants of non-synthesised formanilide derivatives.
\end{abstract}

Keywords: Substituent Effect; Chemical Kinetics; Model Compound; Thermodynamic, Trans Isomer, Cis Isomer

\section{Introduction}

Amides are versatile organic compounds since atoms in the amide group (- $\mathrm{NH}-\mathrm{CO}-$ ) can be attacked by an electrophile. This is a result of the $\pi$-electrons delocalisation along the amide moiety, yielding hybrid ground state structure of the two resonance forms. Biologically active compounds possess amide groups with hydrophobic residue in their close vicinity (Krátky et al., 2011; Dank et al., 2015). These compounds are able to interact and bind with various enzymes/receptors and affect the biological response. Therefore, the reason for the widespread occurrence of amides in modern pharmaceuticals and biologically active compounds is obvious (Pesko et al., 2015). Formanilides represent a suitable group of model compounds as the simplest aromatic molecules with a peptide bond (Marochkin et al., 2013). Formanilides are not as stable as acetanilides, but the amide moiety can be easily modified by various substitutions in order to improve their hydrolytic stability and other properties. On the other hand, a study of the hydrolysis requires only mild experimental conditions.

The amide bond in the formanilides and acetanilides is isolated, freely rotating, and it does not have any significant steric restrictions due to the acyl component of the moiety. Hydrolytic reactivity of formanilide and its 28 ring substituted derivatives with respect to the selected monosubstituted positions in acidic and alkaline environments was studied experimentally (Desai et al., 2015). In di- lute hydrochloric acid $\left(0.01-8 \mathrm{M}, 20-60{ }^{\circ} \mathrm{C}\right)$, the hydrolytic degradation runs via the acid catalysed acyl cleavage bimolecular $\mathrm{A}_{\mathrm{AC}} 2$ mechanism. This mechanism involves protonation of the amide at the carbonyl oxygen. The carbonyl carbon is then attacked by water to form the tetrahedral intermediate which can degrade to products through a series of fast proton transfers or revert to the initial substrate. The modified base-catalysed acyl cleavage bimolecular $\mathrm{B}_{\mathrm{AC}} 2$ mechanism was also reported for sodium hydroxide solutions $(0.01-3 \mathrm{M}, 25$ and $40{ }^{\circ} \mathrm{C}$ ). The reaction solutions were quenched and analysed by high performance liquid chromatography to identify the reaction products. Dependences of the evaluated hydrolysis rate constants on the Hammett constants were also discussed. The authors observed simple linear correlations only for the meta- and para-substituted derivatives, while multilinear regression was used for the ortho substitution effect description. A theoretical view on the alkaline amide hydrolysis of acetanilides including a series of six para-substituted acetanilides was suggested (Cheshemdzhieva et al., 2009). The authors tried to correlate the reactivity with the $\mathrm{NBO}$ atomic charges and electrostatic potentials at the atoms of the reaction centre.

With respect to the published works, we decided to present a systematic theoretical study of reaction enthalpies for both proposed bimolecular reaction schemes (Scheme 1). The main goal was to perform a quantum chemical thermodynamic study of formanilide and its 66 monosubstituted derivatives 
<smiles>O=CCCCCCCCC=O</smiles>

Isomer trans<smiles>Nc1ccccc1</smiles><smiles>O=CNc1ccccc1</smiles><smiles>C[PH-]C</smiles><smiles>[NH3+]c1ccccc1</smiles>

\section{$+\mathrm{HCOOH}$}

Scheme 1. Cumulative reaction scheme for the acidic and alkaline hydrolysis of formanilides.<smiles>O=BN[IH]1=[In]SC=[SH]1</smiles>

Isomer cis

Fig. 1. Schematic structure of formanilide derivatives with atom numbering.

in ortho, meta and para positions (Fig. 1). The evaluated reaction enthalpies were correlated with the experimentally obtained kinetic rate constants of hydrolysis. The obtained dependences were used for the prediction of the hydrolysis rate constants.

\section{Computational details}

The quantum chemical calculations were performed using the Gaussian 09 program package (Frisch et al., 2009). Optimal geometries of the studied molecules in the neutral and ionic forms were calculated in water using the DFT method with B3LYP (Becke's three parameter Lee-Yang-Parr) functional (Lee et al., 1988; Becke, 1988) without any constraints (energy cut-off of $10^{-5} \mathrm{~kJ} \times \mathrm{mol}^{-1}$, final RMS energy gradient below $0.01 \mathrm{~kJ} \times \mathrm{mol}^{-1} \times \mathrm{A}^{-1}$ ). For all calculations, the $6-311++\mathrm{G}(\mathrm{d}, \mathrm{p})$ basis set was employed (Hariharan et al., 1973; Rassolov et al., 1998). The influence of the solvents was approximated by the continuum Solvation Model based on the quantum mechanical charge Density (SMD) (Marenich et al., 2009) of a solute molecule interacting with a continuum. The optimised structures were confirmed to be real minima by a frequency analysis (no imaginary frequencies). The reaction enthalpies, $\Delta_{\mathrm{r}} H\left(\mathrm{~A}_{\mathrm{AC}} 2\right)$, for acidic hydrolysis were calculated based on total enthalpies, $H$, obtained from Eq. 1

$$
\begin{gathered}
\Delta_{\mathrm{r}} H\left(\mathrm{~A}_{\mathrm{AC}^{2}} 2\right)=H\left(\mathrm{R}-\mathrm{NH}_{3}^{+}\right)+H(\mathrm{HCOOH})- \\
-H(\mathrm{R}-\mathrm{NHCO})-H\left(\mathrm{H}_{3} \mathrm{O}^{+}\right)
\end{gathered}
$$

Symbol $H\left(\mathrm{R}-\mathrm{NH}_{3}{ }^{+}\right)$stands for the total enthalpy of

the anilinium ion, $H(\mathrm{HCOOH})$ is the total enthalpy of formic acid (-189.800086 hartree) and $H(\mathrm{R}-$ NHCO) represents the total enthalpy of the parent molecule. The B3LYP(SMD)/6-311++G(d,p) value for hydronium $\mathrm{H}_{3} \mathrm{O}^{+}$in water is -76.846887 hartree. Reaction enthalpies, $\Delta_{\mathrm{r}} H\left(\mathrm{~B}_{\mathrm{AC}} 2\right)$, for alkaline hydrolysis were calculated according to Eq. 2

$$
\begin{gathered}
\Delta_{\mathrm{r}} H\left(\mathrm{~B}_{\mathrm{AC}} 2\right)=H\left(\mathrm{R}-\mathrm{NH}_{2}\right)+H\left(\mathrm{HCOO}^{-}\right)- \\
-H(\mathrm{R}-\mathrm{NHCO})^{-}-H\left(\mathrm{OH}^{-}\right)
\end{gathered}
$$

Symbol $H\left(\mathrm{R}-\mathrm{NH}_{2}\right)$ stands for the total enthalpy of aniline, while $H\left(\mathrm{HCOO}^{-}\right)$is the total enthalpy of deprotonated formic acid (-189.360285 hartree) and the enthalpy of the hydroxyl anion $H\left(\mathrm{OH}^{-}\right)$is -75.966655 hartree. The enthalpies were evaluated for $T=298.15 \mathrm{~K}$.

\section{Results and Discussion}

In case of the parent formanilide molecule, the possible mutual orientation of the carbonyl $\mathrm{C} 8=\mathrm{O}$ group with respect to the N7-H pair leads to two possible conformations (see Fig. 1). The B3LYP calculation for the parent molecule indicates that the trans conformer is practically planar, while the dihedral angle between the aromatic ring and the amide group is $27^{\circ}$ for the cis-isomer. The electronic energy difference is $0.5 \mathrm{~kJ} \times \mathrm{mol}^{-1}$, suggesting similar population of the trans and cis conformers. Ortho substitution influences the mutual orientation of the aromatic ring and the terminal $-\mathrm{NH}-\mathrm{COH}$ moiety, resulting in a more populated trans conformation. The energy differences between trans and cis conformations are in the range from 0.27 to $11.35 \mathrm{~kJ} \times \mathrm{mol}^{-1}$. Therefore, the calculations were performed for the trans conformations.

As already emphasised, the principal aim of this study was to analyse the correlations between the calculated reaction enthalpies for the studied series of formanilides and the experimentally determined rate constants for acidic and alkaline hydrolysis. Under the conditions studied, all investigated molecules were essentially non-dissociated substrates. The obtained Hammett plots are not linear and they display a downward curvature. For meta-substituted formanilides, deactivating groups (e.g. nitro-, cyano- and carboxyl-) led to an increase 
Tab. 1. Hammett substituent constants $\left(\sigma_{\mathrm{p}}, \sigma_{\mathrm{m}}\right)$ (Hansch et al., 1991), acidic hydrolysis rate constants $\left(k_{\mathrm{H}}\right)$ (Desai et al., 2015) and corresponding B3LYP(water) reaction enthalpies $\left(\Delta_{\mathrm{r}} H\right)$.

\begin{tabular}{|c|c|c|c|c|c|c|c|c|c|c|c|}
\hline \multirow{2}{*}{ Substituent } & \multicolumn{2}{|c|}{$\begin{array}{l}\text { Hammett } \\
\text { constants }\end{array}$} & \multicolumn{3}{|c|}{$k_{\mathrm{H}} / \mathrm{hr}^{-1}$} & \multicolumn{3}{|c|}{$\Delta_{\mathrm{r}} H\left(\mathbf{A}_{\mathrm{AC}} 2\right) / \mathrm{kJ} \mathrm{mol}^{-1}$} & \multicolumn{3}{|c|}{$\Delta_{\mathrm{r}} H\left(\mathrm{~B}_{\mathrm{AC}} 2\right) / \mathrm{kJ} \mathrm{mol}^{-1}$} \\
\hline & $\sigma_{\mathrm{p}}$ & $\sigma_{\mathrm{m}}$ & para & meta & ortho & para & meta & ortho & para & meta & ortho \\
\hline$-\mathrm{NO}_{2}$ & 0.78 & 0.71 & 27.30 & 11.30 & 24.9 & -42.394 & -48.503 & -71.078 & -103.114 & -89.267 & -138.180 \\
\hline$-\mathrm{COOH}$ & 0.45 & 0.37 & 18.20 & 8.21 & 24.6 & -50.108 & -54.988 & -95.621 & -93.129 & -84.875 & -133.698 \\
\hline$-\mathrm{Br}$ & 0.23 & 0.39 & 8.32 & 10.80 & 2.57 & -55.566 & -53.615 & -70.833 & -83.449 & -85.838 & -115.798 \\
\hline$-\mathrm{Cl}$ & 0.23 & 0.37 & 7.04 & 9.65 & 7.24 & -56.152 & -53.715 & -76.512 & -83.192 & -85.691 & -115.136 \\
\hline$-\mathrm{H}$ & 0.00 & 0.00 & 7.39 & 7.39 & 7.39 & -60.302 & -60.302 & -60.302 & -81.159 & -81.159 & -81.159 \\
\hline$-\mathrm{Ph}$ & -0.01 & 0.06 & 7.53 & - & 3.17 & -59.334 & -59.814 & -92.546 & -81.889 & -81.551 & -114.388 \\
\hline$-\mathrm{C}_{2} \mathrm{H}_{5}$ & -0.15 & -0.07 & 4.60 & 6.21 & 2.07 & -62.366 & -61.576 & -99.220 & -78.411 & -80.632 & -116.357 \\
\hline -isoC ${ }_{3} \mathrm{H}_{7}$ & -0.15 & -0.05 & 5.42 & 6.05 & 1.39 & -62.264 & -62.151 & -102.234 & -78.555 & -80.233 & -118.841 \\
\hline$-\mathrm{CH}_{3}$ & -0.17 & -0.07 & 5.06 & 6.58 & 2.57 & -62.080 & -61.198 & -97.910 & -77.859 & -80.335 & -115.874 \\
\hline$-\mathrm{OCH}_{3}$ & -0.27 & 0.12 & 2.95 & 8.59 & 5.23 & -63.857 & -59.418 & -91.302 & -75.919 & -82.483 & -111.006 \\
\hline$-\mathrm{OH}$ & -0.37 & 0.12 & 2.67 & 7.80 & 3.81 & -63.285 & -56.293 & -105.984 & -75.420 & -83.126 & -125.614 \\
\hline
\end{tabular}

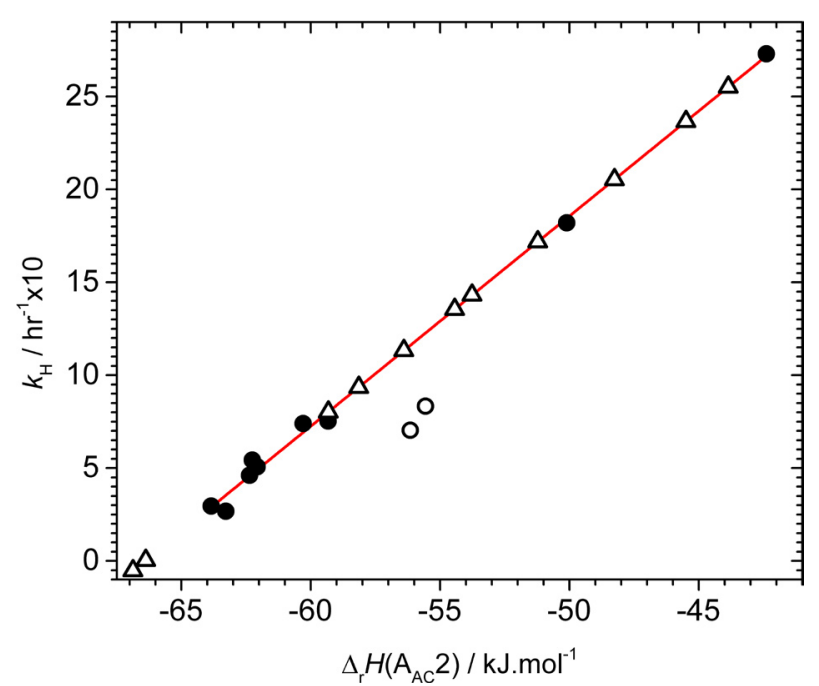

a)

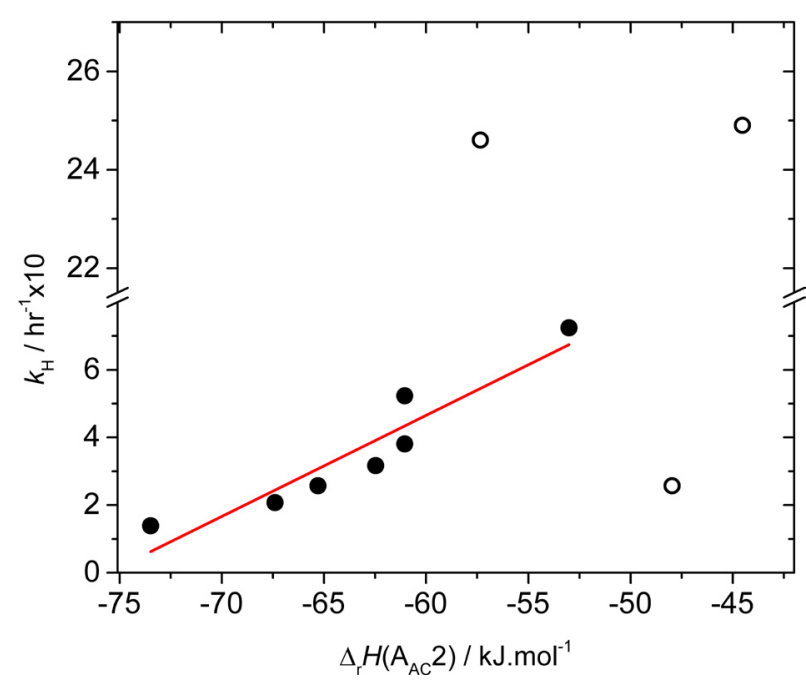

c)

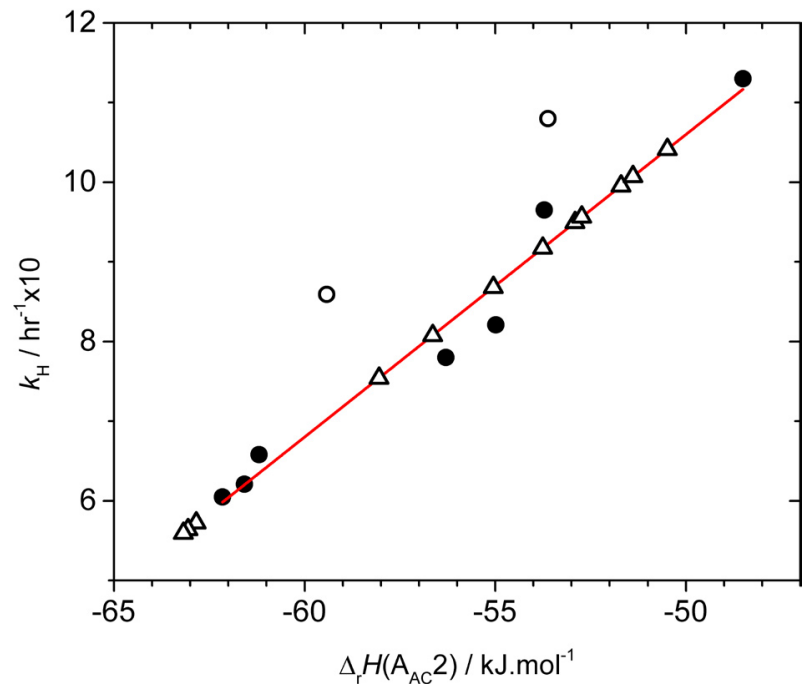

b)

Fig. 2. Correlation of experimental second-order rate constant $\left(k_{\mathrm{H}}\right)$ with the

B3LYP(WATER)/6-311++G(d,p) reaction enthalpies $\left(\Delta_{\mathrm{r}} H\left(\mathrm{~A}_{\mathrm{AC}} 2\right)\right)$ for para $(\mathrm{a})$, meta $(\mathrm{b})$ and ortho (c) formanilide derivatives. Open circles denote the data omitted from the linear regression and the predicted $k_{\mathrm{H}}$ values are indicated by open triangles. Calculations were performed for the trans isomer. 
Tab. 2. Hammett substituent constants $\left(\sigma_{\mathrm{p}}, \sigma_{\mathrm{m}}\right)$ (Hansch et al., 1991) predicted acidic hydrolysis rate constants $\left(k_{\mathrm{H}}\right)$ and corresponding $\mathrm{B} 3 \mathrm{LYP}\left(\right.$ water) reaction enthalpies $\left(\Delta_{\mathrm{r}} H\right)$.

\begin{tabular}{|c|c|c|c|c|c|c|c|c|c|c|}
\hline \multirow{2}{*}{ Substituent } & \multicolumn{2}{|c|}{$\begin{array}{l}\text { Hammett } \\
\text { constants }\end{array}$} & \multicolumn{2}{|c|}{$k_{\mathrm{H}} / \mathbf{h} \mathbf{r}^{-1}$} & \multicolumn{3}{|c|}{$\Delta_{\mathrm{r}} H\left(\mathbf{A}_{\mathrm{AC}} 2\right) / \mathrm{kJ} \mathrm{mol}^{-1}$} & \multicolumn{3}{|c|}{$\Delta_{\mathrm{r}} H\left(\mathrm{~B}_{\mathrm{AC}} 2\right) / \mathrm{kJ} \mathrm{mol}^{-1}$} \\
\hline & $\sigma_{\mathrm{p}}$ & $\sigma_{\mathrm{m}}$ & para & meta & para & meta & ortho & para & meta & ortho \\
\hline$-\mathrm{NO}$ & 0.91 & 0.62 & 31.0 & 10.4 & -38.997 & -50.488 & -42.034 & $-108,606$ & $-87,382$ & $-106,309$ \\
\hline$-\mathrm{CN}$ & 0.66 & 0.56 & 23.7 & 10.0 & -45.500 & -51.696 & -46.839 & $-90,926$ & $-86,833$ & $-98,002$ \\
\hline$-\mathrm{COCl}$ & 0.61 & 0.51 & 25.5 & 10.1 & -43.862 & -51.389 & -47.432 & $-100,528$ & $-87,067$ & $-106,309$ \\
\hline$-\mathrm{CF}_{3}$ & 0.54 & 0.43 & 14.3 & 9.5 & -53.765 & -52.904 & -51.447 & $-91,942$ & $-85,599$ & $-95,952$ \\
\hline$-\mathrm{CCl} 3$ & 0.46 & 0.40 & 17.2 & 9.6 & -51.221 & -52.728 & -46.574 & $-89,918$ & $-85,402$ & $-96,306$ \\
\hline$-\mathrm{CHO}$ & 0.42 & 0.35 & 20.5 & 8.7 & -48.265 & -55.049 & -52.851 & $-95,959$ & $-86,143$ & $-96,695$ \\
\hline$-\mathrm{CCH}$ & 0.23 & 0.21 & 13.5 & 8.1 & -54.434 & -56.643 & -61.665 & $-86,539$ & $-84,142$ & $-97,653$ \\
\hline$-\mathrm{SH}$ & 0.15 & 0.25 & 8.0 & 7.5 & -59.326 & -58.050 & -54.458 & $-79,500$ & $-83,709$ & $-86,437$ \\
\hline$-\mathrm{CH}_{2} \mathrm{~F}$ & 0.11 & 0.33 & 11.3 & 5.7 & -56.398 & -62.841 & -59.945 & $-85,132$ & $-87,710$ & $-87,030$ \\
\hline$-\mathrm{F}$ & 0.06 & 0.34 & 9.3 & 9.2 & -58.150 & -53.757 & -55.382 & $-80,566$ & $-84,449$ & $-90,296$ \\
\hline$-\mathrm{NH}_{2}$ & -0.66 & -0.16 & -0.5 & 5.6 & -66.871 & -63.059 & -62.605 & $-71,521$ & $-80,288$ & $-76,867$ \\
\hline$-\mathrm{NMe}_{2}$ & -0.83 & -0.15 & 0.0 & 5.6 & -66.386 & -63.177 & -64.267 & $-72,136$ & $-79,140$ & $-80,650$ \\
\hline
\end{tabular}
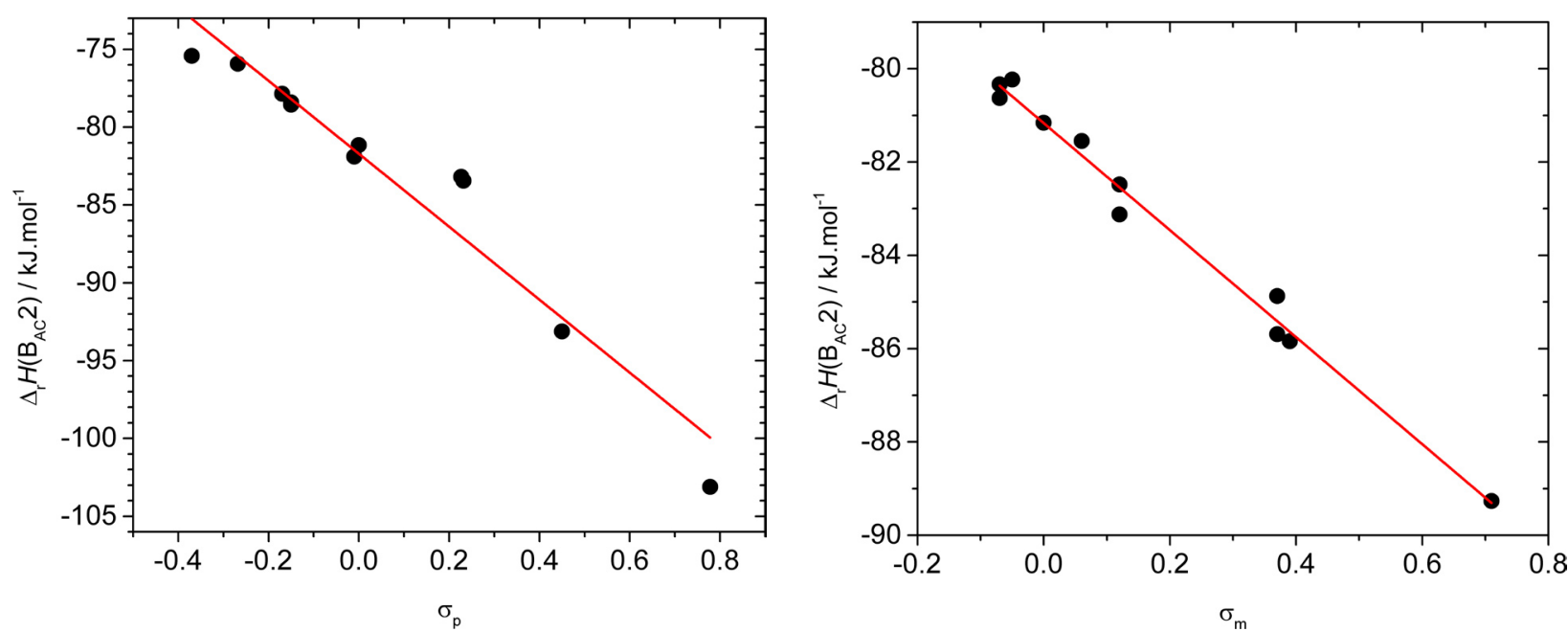

Fig. 3. Correlation of B3LYP(WATER)/6-311++G(d,p) reaction enthalpies $\Delta_{\mathrm{r}} H\left(\mathrm{~B}_{\mathrm{AC}} 2\right)$ for para $(\mathrm{a})$ and meta (b) formanilide derivatives with Hammett constants. Enthalpies were calculated for alkaline hydrolysis at $25^{\circ} \mathrm{C}$ and trans isomers.

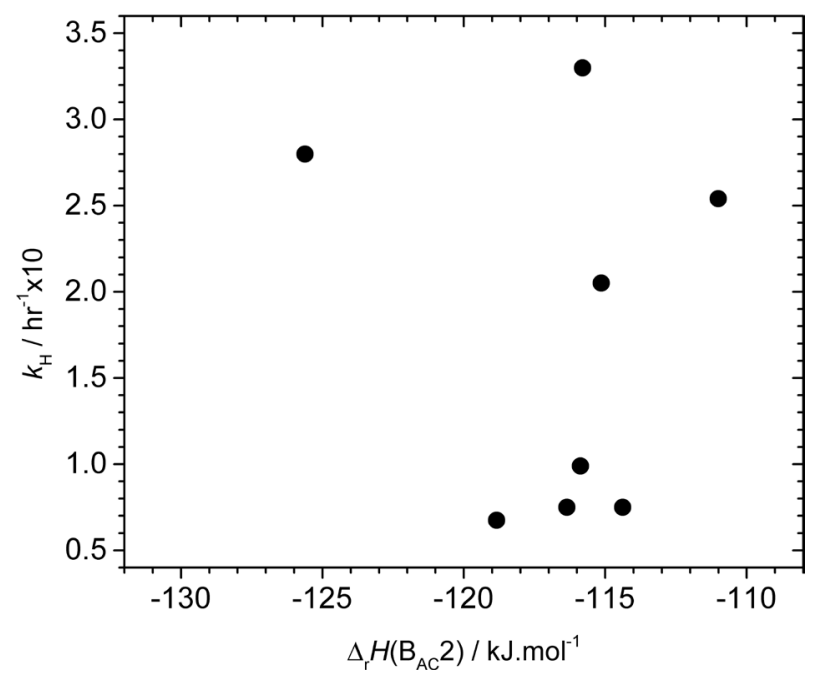

Fig. 4. Dependence of experimental rate constants of alkaline hydrolysis at $25^{\circ} \mathrm{C}\left(k_{\mathrm{H}}\right)$ on the B3LYP(WATER)/6-311++G(d,p) reaction enthalpies $\left(\Delta_{\mathrm{r}} H\left(\mathrm{~B}_{\mathrm{AC}} 2\right)\right)$ for ortho formanilide derivatives. Calculations were performed for the trans isomer. 
in the rate constant $\left(k_{\mathrm{H}}\right)$, whereas activating substituents (e.g. amino-, methyl-, isopropyl-) caused a slight decrease of $k_{\mathrm{H}}$ which increased the electron donating capability. A similar trend can be observed for para substituents except for the strong electronwithdrawing substituents capable of resonance interactions ( $p-\mathrm{NO}_{2}$ and $p$-COOH) (see Fig. 2a).

The data collected in Tab. 1 and depicted in Fig. 2 enable the comparison of the substituent effect on the $k_{\mathrm{H}}$ values with respect to the reaction enthalpy, $\Delta_{\mathrm{r}} H\left(\mathrm{~A}_{\mathrm{AC}} 2\right)$. Linear dependences with $R=0.998$ (Fig. 2a) and 0.981 (Fig. 2b) were found, showing better linearity than the Hammett type dependences for rate constants. From the linear regression depicted in Fig. 2, the following equations were obtained

$$
\begin{aligned}
& k_{\mathrm{H}}=75.1(1.5)+1.131(25) \Delta_{\mathrm{r}} H\left(\mathrm{~A}_{\mathrm{AC}} 2\right) \\
& k_{\mathrm{H}}=29.6(1.7)+0.380(30) \Delta_{\mathrm{r}} H\left(\mathrm{~A}_{\mathrm{AC}} 2\right)
\end{aligned}
$$

Based on Eqs. 3 and 4, $k_{\mathrm{H}}$ values for the non-synthesised derivatives were predicted and are shown in Fig. 2 as open triangles.

A similar linear dependence observed for the ortho derivatives yielded correlation coefficient $R=0.940$ (Fig. 2c). From the linear regression, the following equation was obtained

$$
k_{\mathrm{H}}=-22.6(3.1)+0.298(49) \Delta_{\mathrm{r}} H\left(\mathrm{~A}_{\mathrm{AC}} 2\right)
$$

For $0.1 \mathrm{M}$ sodium hydroxide solutions, Desai and Kirsch (2015) reported that the Hammett plots for hydrolysis of meta- and para-substituted formanilides do not indicate any substituent effect. On the other hand, direct comparison of the reaction enthalpy, $\Delta_{\mathrm{r}} H\left(\mathrm{~B}_{\mathrm{AC}} 2\right)$, for para and meta derivatives with the Hammett constants (see Tab. 2) indicates linear dependences with correlation coefficients $R=0.966$ for para- and 0.994 for meta-substituents

$$
\begin{gathered}
\Delta_{\mathrm{r}} H\left(\mathrm{~B}_{\mathrm{AC}} 2\right) / \mathrm{kJ} \cdot \mathrm{mol}^{-1}=-81.70(69)-23.4(2.1) \sigma_{\mathrm{p}} \\
\Delta_{\mathrm{r}} H\left(\mathrm{~B}_{\mathrm{AC}} 2\right) / \mathrm{kJ} \cdot \mathrm{mol}^{-1}=-81.17(13)-11.47 \sigma_{\mathrm{m}}
\end{gathered}
$$

From Fig. 3, the substituent effect on the reaction enthalpy is evident. The dependence of the rate constants on the reaction enthalpies of para and meta derivatives for alkaline hydrolysis exhibits no linearity, similarly as in case of the ortho derivatives (see Fig. 4). Correlation coefficients evaluated for the linear regressions are lower than 0.70 . As it was reported by Desai and Kirsch (2015), the possible linear dependence can be evaluated only between $\log k_{\text {obs }}$ and the Taft-Kutter-Hansch steric substituent values, $\mathrm{E}_{\mathrm{s}}$.

\section{Conclusions}

A series of compounds representing various para-, meta- and ortho-substituted formanilides were stu- died. Reaction enthalpies for acidic and alkaline hydrolysis were evaluated using the DFT quantum chemical method and correlated with the hydrolysis rate constants published for the bimolecular $\left(\mathrm{A}_{\mathrm{AC}} 2\right)$ mechanism of acid-catalysed acyl cleavage. The obtained linear dependences can be employed to predict rate constant of non-synthesised formanilide derivatives. For the modified base-catalysed acyl cleavage, the bimolecular $\left(\mathrm{B}_{\mathrm{AC}} 2\right)$ mechanism, the reaction enthalpies were correlated with the Hammett constants. In case of the ortho derivatives, no linear dependence between $k_{\mathrm{H}}$ and $\Delta_{\mathrm{r}} H\left(\mathrm{~B}_{\mathrm{AC}} 2\right)$ was found due to the synergic and antagonistic influence of the steric and solvent effects on the molecular electronic structure. Finally, we would like to note that the quantum chemical calculations provide also additional microscopic properties, which can be potentially used to describe the substitution effect, e.g. energies of frontier orbitals, partial charges on selected atoms, dipole moments and the selected bond distances. However, correlations of these quantities with the experimental rate constants were not satisfying. The results obtained can be useful for the development of novel formanilide derivatives.

\section{Acknowledgment}

The work has been supported by the Slovak Grant Agency (1/0594/16 and 1/0416/17) and the Slovak Research and Development Agency (APVV-15-0053). We are grateful to the HPC Center at the Slovak University of Technology in Bratislava, which is a part of the Slovak Infrastructure of High Performance Computing (SIVVP project, ITMS code 26230120002, funded by the European region development funds, ERDF) for the computational time and resources provided.

\section{References}

Becke AD (1988) Phys. Rev. A 38: 3098-3100.

Bender ML, Thomas RJ (1961) J. Am. Chem. Soc 83: 4183-4189.

Cheshmedzhieva D, Ilieva S, Hajieva B, Galabov B (2009) J Phys Org Chem 22: 619-631.

Dank C, Kirchknopf B, Mastalir M, Kählig H, Felsinger S, Roller A, Gstach H (2015) Molecules 20: 1686-1711.

Desai SD, Kirsch LE (2015) International Journal of Chemical Kinetics 47: 471-488.

DeWolfe RH, Newcomb RC (1971) J. Org. Chem. 36: 3870-3878.

Francl MM, Pietro WJ, Hehre WJ, Binkley JS, Gordon MS, DeFrees DJ, Pople JA (1982) J. Chem. Phys. 77: 3654-3665.

Frisch MJ, Trucks GW, Schlegel HB, Scuseria GE, Robb MA, Cheeseman JR, Scalmani G, Barone V, Mennucci B, Petersson GA, Nakatsuji H, Caricato M, Li X, Hratchian HP, Izmaylov AF, Bloino J, Zheng G, Sonnenberg JL, Hada M, Ehara M, Toyota K, Fukuda R, Hasegawa J, Ishida M, Nakajima T, Honda 
Y, Kitao O, Nakai H, Vreven T, Montgomery JA Jr., Peralta JE, Ogliaro F, Bearpark M, Heyd JJ, Brothers E, Kudin KN, Staroverov VN, Keith T, Kobayashi R, Normand J, Raghavachari K, Rendell A, Burant JC, Iyengar SS, Tomasi J, Cossi M, Rega N, Millam JM, Klene M, Knox JE, Cross JB, Bakken V, Adamo C, Jaramillo J, Gomperts R, Stratmann RE, Yazyev O, Austin AJ, Cammi R, Pomelli C, Ochterski JW, Martin RL, Morokuma K, Zakrzewski VG, Voth GA, Salvador P, Dannenberg JJ, Dapprich S, Daniels AD, Farkas O, Foresman JB, Ortiz JV, Cioslowski J, Fox DJ (2009) Gaussian 09, Revision D.01, Gaussian, Inc. Wallingford CT.

Hansch C et al. (1991) Chem. Rew. 91: 165-195.

Hariharan PC, Pople JA (1973) Theor. Chim. Acta 28: 213-222.
Kratky M, Vinsova J (2011) Mini reviews in medicinal chemistry, 11: 956-967.

Lee C, Yang W, Parr RG (1988) Phys Rev B 37: 785-789.

Marenich AV, Cramer CJ, Truhlar DG (2009) J Phys Chem B 113: 6378.

Marochkin II, Dorofeeva OV (2013) Structural Chemistry 24: $233-242$.

Michalík M, Vagánek A, Poliak P (2014) Acta Chimica Slovaca 7: 123-128.

Pesko M, Kos J, Kralova K, Jampilek J (2015) Ind. J. Chem. 54: 1511-1517.

Poliak P, Vagánek A (2013) Acta Chimica Slovaca 6: 64-72.

Rassolov VA, Pople JA, Ratner MA, Windus TL (1998) J. Chem. Phys. 109: 1223-1229. 